\title{
Current Evidence on Dental Implants in HIV-positive Patients
}

\author{
Sunil K Mishra ${ }^{1}$, Ramesh Chowdhary ${ }^{2}$ \\ International Journal of Prosthodontics and Restorative Dentistry (2021): 10.5005/jp-journals-10019-1306
}

Human immunodeficiency virus (HIV) infection may result in the development of acquired immunodeficiency syndrome (AIDS). This syndrome is one of the most devastating global pandemics affecting the health of the public with increased mortality rates. ${ }^{1}$ According to the data provided by World Health Organization in 2020, almost 37.6 million people throughout the world were living with HIV. ${ }^{2}$ Human immunodeficiency virus destroys specific CD4 helper lymphocyte cells in the immune system and makes the affected person more susceptible to opportunistic infections. ${ }^{3}$ Highly active antiretroviral therapy (HAART) was introduced to control HIV infection by increasing the CD4 cell count. ${ }^{4}$ Today dental implant becomes the favorable treatment option for the rehabilitation of partial or complete edentulous patients. Nowadays, the number of HIV patients receiving dental implant treatment is increasing, but not much is known about the survival of dental implants in HIV-positive patients.

Sabbah et al. in their 5-year retrospective study compared the failure rates of dental implants placed in HIV (-) and HIV (+) patients in relation to different risk factors. They found that similar survival rates of implants in HIV (+) patients and HIV (-) patients. The implant failures were more in HIV (+) patients with confounding risk factors..$^{5}$ Oliveira evaluated a group of HIV (+) patients for 12 years who had received the dental implant and found long-term survival of implants which was comparable with that of healthy individuals. ${ }^{6}$

Lemos et al. in their systematic review evaluated the survival of dental implants in HIV (+) patients with a mean duration of follow-up of 47.9 months. Total 821 implants were placed [493 implants in 169 HIV (+) patients; 328 implants in 135 HIV (-) patients]. A mean survival rate of $94.53 \%$ for the implants was found in HIV (+) patients. ${ }^{1}$ Duttenhoefer et al. in their meta-analysis found a $93.1 \%$ of survival rate of dental implants in HIV $(+)$ patients in 2 years of follow-up. ${ }^{7}$

Aghaloo et al. had done a systematic review to find the effect of systemic disease and medication on implant osseointegration and found that there was no direct evidence that HIV (+) patients had decreased rate of implant osseointegration. ${ }^{8}$ Sivakumar et al. had published a meta-analysis recently to find the survival of dental implants in patients with HIV. They found a $95 \%$ survival rate of dental implants in 411 HIV-positive patients with 1109 implants in a mean follow-up of 2.8 years. ${ }^{9}$

Placing dental implants in HIV-positive patients is not a contraindication and the currently available literature evidence suggests a survival rate of dental implants up to $95 \%$. In HIV-positive patients with controlled risk factors and normal CD4 cell counts, dental implants seem to be a suitable treatment modality for the rehabilitation of edentulous conditions.
${ }^{1}$ Department of Prosthodontics, Rama Dental College, Hospital and Research Centre, Kanpur, Uttar Pradesh, India

${ }^{2}$ Department of Prosthodontics, RajaRajeswari Dental College and Hospital, Bengaluru, Karnataka, India

Corresponding Author: Sunil K Mishra, Department of Prosthodontics, Rama Dental College, Hospital and Research Centre, Kanpur, Uttar Pradesh, India, Phone: +91 7697738478, e-mail: sunilmsr200@yahoo. co.in

How to cite this article: Mishra SK, Chowdhary R. Current Evidence on Dental Implants in HIV-positive Patients. Int J Prosthodont Restor Dent 2021;11(1):1.

Source of support: Nil

Conflict of interest: None

\section{References}

1. Lemos CAA, Verri FR, Cruz RS, et al. Survival of dental implants placed in HIV-positive patients: a systematic review. Int J Oral Maxillofac Surg 2018;47(10):1336-1342. DOI: 10.1016/j.ijom.2018.02.010.

2. Global HIV \& AIDS statistics-2019 fact sheet, UNAIDS. Available at: https://www.unaids. org/en/resources/fact-sheet Accessed 15 June 2021.

3. Walker B, McMichael A. The T-Cell response to HIV. Cold Spring Harb Perspect Med 2012;2(11):a007054. DOI: 10.1101/cshperspect. a007054.

4. Benítez-Gutiérrez L, Soriano $\mathrm{V}$, Requena $\mathrm{S}$, et al. Treatment and prevention of HIV infection with long-acting antiretrovirals. Expert Rev Clin Pharmacol 2018;11(5):507-517. DOI: 10.1080/17512433.2018.1453805.

5. Sabbah A, Hicks J, MacNeill B, et al. A retrospective analysis of dental implant survival in HIV patients. J Clin Periodontol 2019;46(3):363372. DOI: 10.1111/jcpe.13077.

6. Oliveira MA, Pallos D, Mecca F, et al. Dental implants in patients seropositive for HIV: a 12-year follow-up study. J Am Dent Assoc 2020;151(11):863-869. DOI: 10.1016/ j.adaj.2020.07.026.

7. Duttenhoefer F, Fuessinger MA, Beckmann Y, et al. Dental implants in immunocompromised patients: a systematic review and metaanalysis. Int J Implant Dent 2019;5(1):43. DOI: 10.1186/s40729-0190191-5.

8. Aghaloo T, Pi-Anfruns J, Moshaverinia A, et al. The effects of systemic diseases and medications on implant osseointegration: a systematic review. Int J Oral Maxillofac Implants 2019;34(Suppl):s35-s49. DOI: 10.11607/jomi.19suppl.g3.

9. Sivakumar I, Arunachalam S, Choudhary S, et al. Does HIV infection affect the survival of dental implants? A systematic review and meta-analysis. Prosthet Dent 2021;125(6):862-869. DOI: 10.1016/j. prosdent.2020.04.001.

(c) Jaypee Brothers Medical Publishers. 2021 Open Access This article is distributed under the terms of the Creative Commons Attribution 4.0 International License (https://creativecommons.org/licenses/by-nc/4.0/), which permits unrestricted use, distribution, and non-commercial reproduction in any medium, provided you give appropriate credit to the original author(s) and the source, provide a link to the Creative Commons license, and indicate if changes were made. The Creative Commons Public Domain Dedication waiver (http://creativecommons.org/publicdomain/zero/1.0/) applies to the data made available in this article, unless otherwise stated. 